\title{
Improvement of diagnostic test-system of the Teshen illness on the basis of solid-phase immunoenzymatic analysis
}

\author{
T. Bova, \\ S. Derevianko, \\ L. Reshotko, \\ Candidates of biological sciences Institute of Agricultural Microbiology and Agro-Industrial \\ Production of NAAS
}

The purpose. To improve immunoenzymatic test-system for detection of immunoglobulins of class $G$ to a virus of Teshen illness in blood serum of pigs. Methods. Virologic, serologic, immunoenzymatic, instrumental and statistical methods offered by foreign and domestic scientists, as well as own ones. Results. At use of new industrial strain Porcine teschovirus of the first serotype Dneprovsiy-34 they improved diagnostics of Teshen illness of pigs on the basis of solidphase immunoenzymatic analysis. Conclusions. Specificity of the test-system makes $100 \%$, responsivity $95,6 \%$. Application of the test-system allows making the diagnosis during 7 hours, that it is much less in comparison with reaction of neutralization.

Key words: enzootic encephalomyelitis (Teshen illness) of pigs, diagnostic test-system, solidphase immunoenzymatic analysis.

The Teschen disease (Teschovirus encephalomyelitis, enzootic encephalomyelitis, Teschen disease) of pigs is one of the most dangerous diseases, the causative agent of which is Porcine teschovirus of the first serotype (PTV-1), which belongs to the species Teschovirus $A$ of the genus Teschovirus of the family Picornaviridae. The defeat of the central nervous system by the virus is accompanied by a non-inflammatory of the brain and its membranes, leading to disorders of coordination of movements, hypersensitivity, convulsive contractions of the muscles of the body, progressive paresis and paralysis of the limbs in the pigs. The incidence of pigs on enzootic encephalomyelitis ranges from 14 to $90 \%$, and on average up to $40 \%$, of which deaths can range from $20 \%$ to $100 \%$ [1].

Teschovirus 2-6, 9 and 10 serotypes cause sporadic outbreaks of encephalomyelitis [2]. Clinical and pathoanatomical features of the disease caused by the tesovirus of different serotypes do not differ from each other. In addition, these symptoms are typical of Aujeszky disease, classical swine fever, hemagglutinating encephalomyelitis and other infectious diseases. Thus, a laboratory diagnosis that prevents the isolation and identification of the pathogen and the detection of antibodies in serum of pigs is crucial for establishing the final diagnosis. [3]

One of the main methods of preventing disease is animal vaccination. Existing live and inactivated vaccines against Teschen disease today can not meet modern requirements in many ways [4]. The basic requirement for modern inactivated vaccines is the antigenic relevance of the vaccine strains to the epizootic, lack of reactogenicity, and the formation of short-term intense and long-term immunity.

Therefore, the purpose of our work was to improve the laboratory diagnosis of Teschen's disease on the basis of serological, immunological and molecular genetic methods in accordance with the requirements of FEM and to develop an inactivated vaccine.

Materials and methods. In this work were used the strains PTV-1 Chernihivsky-2372 and Dniprovsky-34,which allocated on the territory of Ukraine, reference strains: PTV-1 Talfan, Tirol, Teschen 199 and strains PTV 2-11 serotypes: O 3b, O 2b, PS 36, F 26, PS 37, F 43, UKG 173/74, 
VIR 2899/84, VIR 460 / 88, Dresden, Porcine sapelovirus strain (PSV) V 13 of Sapelovirus $A$ type and strains of Enterovirus G (EV-G) UKG $410 / 73$ and LP 54 provided by Professor Malta Dawber (Germany), which are stored in the collection of strains of virus Institute of Agricultural Microbiology and Agro-Industrial Production NAAS. The oligonucleotide species-specific primers created by us for PTV, PSV and EV-G have been used to develop molecular genetic methods for diagnosing Teschen disease. [5]

Isolation and cultivation of the viruses were carried out in digested embryonic kidney cells of pigs (EKCP) and kidney newborn Syrian hamster (BHK-21). Hyperimmune sera of blood were obtained in rabbits according to the scheme developed by us [6].

Neutralization reaction of the virus (RN), enzyme-linked immunosorbent assay (ELISA), immunofluorescence reaction (RIF), immune peroxidase reaction (IPR), polymerase chain reaction with reverse transcription (RT PCR) were conducted in accordance with the guidelines [7].

Results. For the improvement and development of new diagnostic test-systems was used the strain Dniprovsky-34, capable of reproduction in digested embryonic kidney cells of pigs and BHK-21, where it causes a cytopathic effect in 24-72 hours, and accumulates in the titre 7,0-8,5 $\mathrm{lg} \mathrm{TCD_{50 }} / \mathrm{cm}^{3}$.

At the immunization of rabbits, blood serums with titres of anti-viral antibodies have been obtained at least 1: 512. As a result of studying the antigenic properties of the strain Dniprovsky-34 in RN with reference strains, it was found that the strain indicated antigenically related to PTV-1 Talfan, Teschen 199, Tirol, C 2372 at $100 \%$ and does not enter into serological responses with reference strains of other serotypes of PTV, PSV and EV-G. High antigenic affinity to the epizootic and reference strains of PTV-1 and high immunogenicity led to the selection of the strain Dniprovsky-34 as a production. According to the results of commission tests, the Dniprovsky-34 strain was deposited with the Depository of the State Scientific-Control Institute for Biotechnology and strains of microorganisms under the registration number 486 and the patent of Ukraine was obtained for a utility model [8].

For its use sets of diagnostic sets of Teschen disease have been developed in RN, RIF, ELISA and IPR.

A set of diagnostic tumors of Tesha in neutralization reaction is used to identify viruses, separated from pigs, and the detection of anti-viral antibodies in serum animals. It is planned to conduct RN as a traditional one, and by a micro-method, which reduces the use of the reaction mixture by 10 times. The results are recorded on 4-5 and 7-8 days. Absence cytopathic effect (CPA) during the observation period indicates the presence of virus or antibodies to the Teschen disease causative agent in the investigated materials.

In order to shorten the diagnosis was developed a test system for rapid diagnosis based on RIF and IPR. Test systems are used to identify the pathogen in smears-reflections of the brain and spinal cord and virus identification, separated from the deadforcedly killed in the stage of paresis and paralysis of sick animals. The results of immunofluorescence reaction are monitored using a luminescent microscope. In positive cases, a specific glow appears in the form of a bright green brilliant luminescence of cells in the absence of glow on the glasses with negative serum. Accounting results immune peroxidase reaction spend visually or under an optical microscope. In positive cases, there are yellowish or brown crystals. Developed test systems allow you to diagnose within a few hours.

For the use of the strain Dniprovsky-34 a diagnostic test system was developed immunoassay analysis to detect Class $\mathrm{G}$ immunoglobulins to the pathogens of Tetanus in serum of pigs. On one tablet, you can explore 22 samples in four replays. The results are recorded on a reader at $450 \mathrm{~nm} /$ $620 \mathrm{~nm}$. The diagnosis is up to 8 hours.

For a specific identification of the pathogen of enzootic encephalomyelitis, a set of diagnosticums for RT PCR was developed based on oligonucleotide primers developed by us: 


\section{Sense Primer: TeschoF51 5'- CCAGCAGCCTCTGTTCAGAAAG}

Antisense Primer: TeschoR51 5'- GC(A/G)TACTTGTATGAGGCCCATC

Primers flank the portion of the RNA molecule with a length of 650 nucleotide residues, starting with 5271 to 5908 nucleotides (AF296096). Their identity for all tesovirus pigs is $100 \%$ based on the analysis of the gene bank.

The amplification of specific cDNA sites of infectious agents was carried out according to the programs presented in the table. Detection of the reaction products - by electrophoresis in a $1.5 \%$ agarose gel, brominated-colored etidium using a tris borate buffer at a voltage gradient of $10 \mathrm{~V} / \mathrm{cm}$.

\section{Program for amplification of specific DNA region}

\begin{tabular}{|c|c|c|c|}
\hline № cycle & $\begin{array}{l}\text { Amplification temperature } \\
\text { Tesovirus of pigs, }{ }^{\circ} \mathrm{C}\end{array}$ & $\begin{array}{l}\text { Time, } \\
\text { min. }\end{array}$ & Amount of cycles \\
\hline 1 & 95 & 5 & 1 \\
\hline \multirow{3}{*}{2} & 94 & 1 & \multirow{3}{*}{5} \\
\hline & 58 & 1 & \\
\hline & 74 & 1 & \\
\hline \multirow{3}{*}{3} & 94 & 0,5 & \multirow{3}{*}{35} \\
\hline & 58 & 0,5 & \\
\hline & 73 & 0,5 & \\
\hline 4 & 72 & 5 & 1 \\
\hline 5 & & Storage & \\
\hline
\end{tabular}

The results were evaluated when viewing the gel after electrophoresis on a transilluminator under UV light by the presence (or absence) red-orange DNA fragments of the appropriate size. The specificity of the amplified DNA fragment was determined by its size relative to the fragments of standard markers. The diagnosis time is up to 8 hours.

In the course of commission studies, the high specificity and sensitivity of the developed test systems has been confirmed. The diagnostic tools developed by us allow to diagnose in the short term in accordance with the recommendations of the World Organisation for Animal Health (OIE).

On the basis of the PTV-1 strain Dniprovsky-34 an inactivated vaccine was developed for the specific prevention of Teschen pig disease and its commision tests were carried out. A single dose of $2 \mathrm{~cm}^{3}$ vaccine contributes to the formation of a specific immunity in pigs to the Teschen disease causing agent for 7 days and lasts for 11 months. The maximum level of virus-neutralizing antibodies in the blood of vaccinated animals at 60 days reached 1: 8192. The average geometric titre of antibodies is 1: 512 , which protects vaccinated pigs even when intracerebral administration of 10 lethal doses of the control epizootic highly virulent strain of Chernyhivsky-2372 Tillage of pigs.

\section{Conclusions.}

The means of diagnostics and specific prophylaxis of Teschen disease have been improved. According to the requirements of OIE, amendments to the current "Instructions on measures for the prevention and control of enzootic encephalomyelitis (Teschen disease) of pigs", namely: to recommend for the diagnosis of the use of test systems based on immunohistochemistry, enzymelinked immunosorbent assay and the species identification of the pathogen in polymerase chain reaction with reverse transcription. According to the modern nomenclature and taxonomy of viruses it is necessary to change the name of the pathogen. 


\section{Bibliography}

1. Romanenko V.F., Soroka V.Y., Pruss O.H. Rekomendatsii po diahnostike i meram bor'by s enzootychesksm tntsefalomyelstom (bolezn'yu Teshena) sviney. K, 1992. - $17 \mathrm{s..}$

2. Witte von K.H. Typisierung von 17 porzinen Enterovirusisolaten aus Polioenzephalomyelitisf llen der Jahre 1983-1991/Witte von K.H., Auerbach J., Loss K.U., Neuhaus S. \& Prager D.//DTW Dtsch. Tierarztl. Wochenschr. - 1994. - Vol. 101. - P. 453-492.

3. OIE. Manual of Standarts for Diagnostic Test and Vaccinees. - 6 Ed. - Paris, 2008. - 957 p.

4. Buzun A.Y. Podtipovye razlichiya sredi shtamov i yzolyatov vozbuditelya bolezni Teshena/A.Y. Buzun, M.V. Babkin//Veterinarna meditsina. - 2000. - T. 78. - S. 23-28.

5. Holovko A.M. Konstruyuvannya vydospetsyfichnykh praymeriv dlya molekulyarno-henetychnoyi identyfikatsiyi teshovirusiv ta enterovirusiv A i V/Holovko A.M., Derevianko S.V., Bova T.O., Soroka V.I., Katsymon V.V.//Mizhvidomchyy tematychnyy nauk. zb.: "Sil's'kohospodars'ka mikrobiolohiya". Chernihiv: TsNTEI, 2009. - Vyp. 10. - S. 156-165.

6. Pat. 58734 Ukrayina, MPK G01N 33/53 (2006.01) Sposib oderzhannya hiperimunnoyi syrovatky krovi do virusiv tvaryn i roslyn/Volkova I.V., Bova T.O., Derevianko S.V.; zayavnyk i patentovlasnyk Instytut sil's'kohospodars'koyi mikrobiolohiyi NAAN. - № u201011151; zayavl. 17.09.2010; opubl. 26.04.2011, Byul. № 8 .

7. Bova T.O. Metodychni rekomendatsiyi $z$ virusolohichnoho monitorynhu enzootychnoho entsefalomiyelitu (hvoroby Teshena) svyney Bova T.O., Soroka V.I., Derevianko S.V., Reshot'ko L.M., Bozhok L.V., Holovko A.M., Katsymon V.V. Instytut sil's'kohospodars'koyi mikrobiolohiyi ta ahropromyslovoho vyrobnytstva NAAN, Chernihiv: ChDTsNII. - 2014. - 19 s.

8. Pat. 57372 Ukrayina, MPK (2011.01) S12N 7/00, A61K 39/125, A61K 39/187 (2011.01), C12R $1 / 92$ (2006.01). Shtam Porcine teschovirus dlya vyrobnytstva veterynarnykh imunobiolohichnykh preparativ/Derevianko S.V., Soroka V.I., Bokun A.O., Bozhok L.V., Bova T.O. - Zayavnyk i patentovlasnyk Instytut sil's'kohospodars'koyi mikrobiolohiyi NAAN. - № u201009325; zayavl. 26.07.2010; opubl. 25.02.2011, byul. № 4 . 